\title{
Constraints in the application of biotechnology to cassava production in Nigeria
}

\author{
Alamu Salawu Abideen \\ Economic Policy Research Department, Nigerian Institute of Social and Economic Research, PMB 5, \\ UI Post Office, Ibadan, Nigeria
}

\begin{abstract}
Biotechnology has potential to enhance the production of agricultural and industrial products for achieving food security and economic development. In agriculture, biotechnology enhances the production of high yielding and disease resistance crops necessary for achieving food security and industrial development. This paper examines the constraints in the application of biotechnology research to the production of cassava in Nigeria. The study utilized primary data collected through questionnaire administration and interview from three research institutions working on cassava biotechnology in Nigeria. Findings showed that weak infrastructural facilities, poor funding, inadequate competent personnel and absence of appropriate legislation are the constraints in the application of biotechnology to cassava production in Nigeria. In addition, one out of the three research institutions has adequate and regular electricity supply through its own captive power plant while the remaining two research institutions relied more on electricity from the national grid. Inadequate funding and shortage of competent personnel were peculiar challenge confronting all the research institutions covered by the study. The study recommends improvement in electricity supply, production of more biotechnology scientists and adequate funding to enhance biotechnology research in Nigeria.
\end{abstract}

Keywords: biotechnology; cassava production; constraints; Nigeria

\section{INTRODUCTION}

Technology is central to the achievement of a large, strong, diversified, sustainable and competitive economy necessary for improving the quality of life of the people. Coad and Reid (2012) define technology as the utilization of equipment, software, instrument, knowledge, technique and organizational methods to design, develop and market products and services. The recognition of the vital role of technology in socio-economic emancipation led to its development by countries across the globe. The major technologies currently making waves in the global economy are nanotechnology, information and communication technology and biotechnology.

According to Acharya and Mugabe (1996), biotechnology is a cluster of techniques used to modify and / or use organism to produce goods and services. It is impacting positively on the economic development of many countries around the globe because it enhances the production of drugs, food items, crops and animals among other things. The great potential of biotechnology led to the intensification of research and development (R\&D) efforts on 
agriculture, medicine, pharmacy and environment by the United States of America (USA), Canada and United Kingdom among others.

In the area of agriculture, biotechnology allows for the use of molecular markers to study plant genetic diversity while genetic engineering (an aspect of biotechnology) allows for the modification of plant genetic make-up in order to develop new plant varieties, which could not be achieved by other plant breeding methods (Spore, 1996). More importantly, biotechnology research provides opportunities for overcoming natural obstacles in crop breeding processes. For example, through tissue culture, several plantlets can be made from the fragments of plant shoot. As a result, one parent plant gives rise to millions of diseasefree identical plantlets which can be used to produce healthy planting materials in the future. Thus, biotechnology research has the capability to provide solution to some of the challenges facing the production of cassava (Manihot esculenta Crantz) and other crops like, cowpea, tomato, rice and potato that are vital in achieving food security in Nigeria and other countries.

Cassava is an important staple food and cash crop in Nigeria, Ghana and the Republic of Congo where it plays principal roles in achieving food security (Agwu and Anyaeche, 2007). Through simple traditional processing, cassava tubers yield several food products like fufu, garri, lafun and tapioca that are used as staple food in many parts of Africa. Among the starchy food crops, cassava gives a carbohydrate production of about 40 percent higher than rice and 25 percent higher than maize with the result that cassava is the cheapest source of calories for both human nutrition and animal feeding (Tonnkari, 2004). Nweke et. al. (2002) observed that 80 percent of Nigerians living in the rural areas eat a cassava meal at least once a week while majority eat cassava meal at least once daily. From a global point of view, cassava provides food for over 500 million people in developing countries (Roca et al 1992). The crop's ability to provide a staple food base is a function of its flexible planting, harvesting and processing strategies as well as its relative tolerance to poor soil condition and other climatic challenges.

Cassava is one of the major crops considered for improvement in yield under the agricultural transformation agenda of the present civilian administration in Nigeria. The Federal Government of Nigeria (FGN) focus on cassava for the production of ethanol, starch, glucose, live-stock feed and so on, in addition to its principal role as major staple food. For cassava to assume these roles in the Nigerian economy, some of its production challenges such as incidence of pest (insects and diseases) must be given adequate attention.

In order to address these challenges, the FGN has been investing on biotechnology research, with a view to ensure improvement in production level. Brink et al (1998) reported some of the specific government efforts with regard to the application of biotechnology in the country to include:

- Long term conservation of cassava, yam, banana and medicinal plants

- Genetic engineering of cowpea for virus and insect resistance;

- Transformation and regeneration of cowpea, yam, cassava and banana;

- Human resource development through group training, degree-related training, fellowships and networking.

Other notable effort of the FGN in the area of biotechnology was the establishment of biotechnology related institutions like National Centre for Genetic Resources and Biotechnology (NACGRAB) and National Biotechnology Development Agency (NABDA).

In addition, the FGN has also put in place biotechnology policy to ensure that Nigeria benefit from the potential of the biotechnology research. Despite all these efforts, cassava production has not benefitted from biotechnology research in the country. For example, study 
conducted by Alamu (2010) shows that no cassava variety has been produced through biotechnology research in Nigeria. This paper examines the challenges in the application of biotechnology research for the improvement of cassava production in Nigeria.

\section{METHODOLOGY}

The study conducted a survey on constraints on the improvement of cassava through biotechnology in Nigeria. The survey was conducted on Research Institutions (RIs) in the country that are working on cassava biotechnology research.

\section{1. Types of Data}

This study utilised primary data collected through questionnaire and interview. The primary data collected for the study included: type of equipment and materials required for cassava biotechnology research, adequacy and competency of human capacity as well as the challenges (fund, equipment, machineries and other infrastructure) in cassava biotechnology research.

\section{2. Sources of Data}

Three research institutions were selected for the study based on their several years of research and development activities on agriculture and food production in Nigeria. The institutions were the International Institute of Tropical Agriculture (IITA), Ibadan, the National Root Crop Research Institute (NRCRI), Umudike, the National Centre for Biotechnology Research (NACGRAB), Ibadan and Institute for Agricultural Research and Training (IAR\&T), Moor Plantation, Ibadan.

\section{3. Data Collection Instrument}

The primary data used for this study were collected with the aid of questionnaire and interview guide. These two research instruments were administered on a researcher/ scientist selected by the responding institutions.

\section{4. Data Collection Procedure}

Enquiry was made in the selected institutions select a respondent for the administration of questionnaire and conduction of interview. The administrative departments of the selected institutions were visited in order to select a Principal Scientist or Researcher working on cassava biotechnology research. The Scientists or Research Associates selected were contacted for data collection purposes.

\section{5. Data Analytical Technique}

Both quantitative and qualitative data collected for this study were reported based on identified similarities and differences existing among the institutions that supplied the data. Content analysis was used for analyzing data obtained from in-depth interviews while Tables were used to present the results of data obtained through questionnaire. 


\section{RESULTS AND DISCUSSIONS}

\section{1. Background Information of Responding Institutions}

The results of analysis of data showed that three research institutions that are applying biotechnology research for improving cassava are all located in southern part of the country (Table 1). While two of them are located in Ibadan, south-west Nigeria, the other one is located in Umudike, Imo state, in the south-east of the country.

The research institutions that are located in Ibadan are the National Centre for Genetic Research and Biotechnology (NACGRAB) and the International Institute of Tropical Agriculture (IITA).

While IITA was established in 1987, NACGRAB was established in 1967. The NRCRI was also established in 1967. The ownership structure and source of fund for these institutions also varies. For example, while NACGRAB and NRCRI were established and funded by the Federal Government of Nigeria (FGN), IITA is an international research institution, controlled and funded by the Consultative Group on International Agricultural Research (CGIAR).

Table 1. Background Information of the Responding Institutions.

\begin{tabular}{|c|c|c|c|c|}
\hline Name of Institution & Location & $\begin{array}{c}\text { Geo-Political } \\
\text { Zone }\end{array}$ & Ownership & $\begin{array}{c}\text { Year of } \\
\text { Establishment }\end{array}$ \\
\hline IITA & Ibadan & South-West & International & 1967 \\
\hline NACGRAB & Ibadan & South-West & FGN & 1987 \\
\hline NRCRI & Umudike & South-East & FGN & 1967 \\
\hline
\end{tabular}

Source: Field Survey (2011).

Table 2 shows the level of availability and degree of adequacy of various infrastructural facilities necessary for cassava biotechnology research in the three institutions under consideration. The Table shows that only IITA has most of the required infrastructural facilities for an effective and efficient biotechnology research.

Findings also showed that IITA as an international research institute has adequate and regular power and water supply as well as availability of screen house, molecular biology and tissue culture laboratories. However the reverse is the case with the other two institutions. NACGRAB has fairly equipped laboratory, good aseptic transfer area, adequate growth room, moderate screen house and acclimatization chamber.

The institute does not have regular and adequate power and water supply. The condition of infrastructural facilities in NRCRI seems to be unsatisfactory as screen house, aseptic transfer area and growth room vital for biotechnology research are not in place.

The inadequacy of infrastructural facilities in the laboratories of NACGRAB and NRCRI constitutes a clog in the wheel of progress of their biotechnology research activities. Findings revealed that some of their experiments had to be abandoned as a result of power interruption.

In addition, some major experiments cannot be embarked upon as a result of inadequacy of infrastructural facilities. Similarly, inadequate infrastructure hinders these institutions collaborative efforts with other institutions. 
Table 2. Level of Adequacy of Infrastructural Facilities in the Responding Institutions.

\begin{tabular}{|c|c|c|c|c|}
\hline \multirow{2}{*}{ S/No. } & \multirow{2}{*}{ Facility } & \multicolumn{3}{|c|}{ Level of Adequacy } \\
\hline & & IITA & NACCGRAB & NRCRI \\
\hline 1. & Laboratory & Well Equipped & Fairly Equipped & Fairly Equipped \\
\hline 2. & $\begin{array}{c}\text { Aseptic Transfer } \\
\text { Area } \\
\end{array}$ & Good & Good & Not Exist \\
\hline 3. & Growth Room & Good & Adequate & Not Exist \\
\hline 4. & Electricity & $\begin{array}{l}\text { Regular and } \\
\text { Adequate }\end{array}$ & $\begin{array}{l}\text { Irregular and } \\
\text { Inadequate }\end{array}$ & $\begin{array}{c}\text { Irregular and } 30-40 \% \\
\text { Adequate }\end{array}$ \\
\hline 5. & Screen House & Standard & Moderate & Not Exist \\
\hline 6. & $\begin{array}{c}\text { Acclimatization } \\
\text { Chamber }\end{array}$ & Good & Moderate & Not Exist \\
\hline 7 & Water & $\begin{array}{l}\text { Adequate and } \\
\text { Regular }\end{array}$ & Fairly Adequate & Adequate and Regular \\
\hline
\end{tabular}

Source: Field Survey (2011).

\section{2. Funding of Cassava Biotechnology Research}

Research and Development (R\&D) activities have been identified as capital intensive projects throughout the world. This is based on the fact that fund is required for the procurement of various machineries and equipment as well as payment of other logistics. As a result, adequate and regular provision of fund is a prerequisite for efficient and effective $R \& D$ activities. The same applies to biotechnology research because a lot of machineries and equipment and other infrastructural facilities required for relevant activities are capital intensive. In addition, fund is always required to pay for the services of highly skilled personnel involved in the process. .

From the global view point, sources of fund for research activities usually vary from public fund (government), to private donors and international organizations. At times, ownership of a particular research institution often determines its major source of funding. For example, in developing countries such as Nigeria, most of the R\&D institutions are owned by the public and are solely funded by the government.

This study reveals that two of the three institutions are owned and funded by the Federal Government of Nigeria (FGN). NACGRAB for instance is solely funded by the FGN. The NRCRI however, derives $90 \%$ of its fund for biotechnology research from the FGN while the remaining $10 \%$ comes from some donor agencies (Table 3 ). The IITA, being an international organization derives greater part of its fund for research from international donors through the Consultative Group on International Agricultural Research (CGIAR). Specifically, the Institute obtains about 90 percent of its research fund from the CGIAR system while the remaining $10 \%$ is provided by other donor agencies. The other donor agencies are various countries across the world such as USA, UK, Canada and Nigeria among others. There are also corporate donors which include Shell Petroleum Corporation. However the contributions of both the FGN and Shell were claimed to be less than 5 percent of total grants available for research. 
Funding of R\&D activities majorly or solely from the public funds is a major problem in obtaining adequate fund for research activities. This is because government as an institution has a lot of responsibilities to discharge with the available public fund. As a result, the available public fund may not be enough to carry out the available developmental projects in addition to funding R\&D activities. The implications of dependency of R\&D institutions solely on public funds are many. In the first instance, such institutions will not have adequate funds for their R\&D activities. Again, such institutions will not be able to embark on concrete research activities that have direct relevance to the economic development of the country.

Table 3. Distribution of Institutions by Sources of Fund.

\begin{tabular}{|c|c|c|c|}
\hline \multirow{2}{*}{ Institution } & \multicolumn{3}{|c|}{ Sources of Funds (\%) } \\
\cline { 2 - 4 } & Public Fund (FGN) & Other Donors & External Agency \\
\hline IITA & 5 & 5 & 90 \\
\hline NACGRAB & 100 & Nil & Nil \\
\hline NRCRI & 90 & 10 & Nil \\
\hline
\end{tabular}

Source: Field Survey, 2011

With regard to availability of adequate fund for carrying out biotechnology research, the story remains the same among all the respondent institutions. This is because available funds for carrying out their biotechnology research on cassava production have been quite inadequate over the years. According to IITA Cassava Geneticist

'Funding of R\&D activities in IITA has been unimpressive due to so many factors. As a result, some research programmes are folding up while some may be terminated if the situation does not improve'. A NACGRAB official in his own view claimed that ' $R \& D$ activities are yet to be given the required attention in terms of funding and provision of other logistics in Nigeria. Thus, the impacts of $R \& D$ activities on the nation's economic development has been low'

\section{3. Major Constraints in Cassava Biotechnology Research in Nigeria}

Nigeria is a country that has been identified to be technologically poor. The situation is compounded by the fact that despite the available natural resources, Nigeria is still economically poor. The multidimensional technological problems of the nation contribute to high level of poverty and other socioeconomic problems in the country. In order to develop Nigerian economy, the technological challenges of the nation must be addressed.

This study identified some of the challenges confronting cassava biotechnology research in the country with a view to provide solution so that Nigeria can benefit from the great potential of biotechnology for food production and poverty alleviation. The responding institutions enumerated some of the problems militating against effective and efficient biotechnology research in their domains to include shortage of skilled manpower, epileptic power supply, lack of efficient and reliable Internet connectivity, bureaucratic problem and inadequate fund.

The results of data collected on IITA show that the institution is not confronted with the problem of infrastructure such as electricity, water or Internet connectivity and well equipped laboratory but with inadequate skilled manpower and lack of adequate fund. The institute has 
its own captive electricity and water supply plants. The case of both NRCRI and NACGRAB are quite different because they are confronted with the problems of epileptic power supply, non-availability of necessary reagent and well equipped laboratory and functional Internet connectivity in addition to inadequate funding. In a situation where adequate fund is not available for research activities, meaningful R\&D activities cannot be embarked upon. This is because most of the required $R \& D$ equipment will not be available. Inadequate funding of research activities is a major impediment in Science and Technology (S\&T) development. Under such ugly situation, there may be no fund for training of personnel and for organizing workshops and seminars. In addition, the situation may be so terrible that no fund is available for payment of staff salaries and allowances.

\section{CONCLUSIONS / RECOMMENDATION}

In order to ensure that biotechnology research contributes positively to cassava production in Nigeria, the following recommendations are offered, based on the findings of this study. These recommendations are discussed under the following sub-headings:

- Needs for the Provision of Adequate and Reliable Infrastructure:

In the first instance, adequate and reliable infrastructure most especially electricity should be provided for all the Research and Development Institutions (RDIs) in the country for running various equipment and machineries.

- High Commitment to High Level Manpower Development:

There is the need for production of adequate competent personnel for biotechnology research in Nigeria through the provision of scholarship for students in biotechnology research while biotechnology, molecular biology and genetics laboratories should be well equipped.

- Adequate and Regular Funding of Biotechnology Research:

R\&D activities have been identified as capital intensive though the return on investment is usually high. Government should provide adequate fund for biotechnology research in Nigeria. Again, private organizations should complement government efforts by contributing part of their profit for funding research activities. This becomes practicable if the matter is backed-up with appropriate legislation by the National Assembly (NAS).

\section{References}

[1] Acharya R., J. Mugabe (1996). Biotechnology in Developing Countries: Critical Issues of Technological Capability Building. Annual Review of Biotechnology.

[2] Alamu A. S. (2010). Biotechnology Research and Cassava Production in Nigeria. NISER Monograph Series, 2011.

[3] Agwu A. E, Anyaeche C. L., African Journal of Biotechnology 6 (2007) 089-098.

[4] Brink J. A., R. W. Barbara, E. J. Dasilva (1998). Plant Biotechnology: A Tool for Development in Africa. Electronic Journal of Biotechnology (1998) 1-3.

[5] Coad A., Reid A. (2012). The Role of Technology in Economic Development: Rethinking Innovation and Enterprise Policy. Scotland Technopolis Group. 
[6] Nweke F. I., Spencer D. S. C., Lynam J. K. (2002). The Cassava Transformation: Africa's Best-Kept Secret. Michigan State University Press, East Lansing.

[7] Roca W. M., Henry G., Angel F., Sarria R., Agric biotech news information 4 (1992) 303-308.

[8] Spore (1996) The Promise of Biotechnology in Agriculture. Spore No. 66, November December. A Publication of the Technical Centre for Agriculture and Rural Cooperation (CTA).

[9] Tonukari N. J., Cassava and the Future of Starch. Electronic Journal of Biotechnology 7(1) (2004). 